\title{
Clinical evaluation of hareetakyadi gutika on kaphaja kasa
}

\author{
Research article
}

\section{Deeja $\mathbf{C R}^{1^{*}}$, Satya Priya $\mathrm{T}^{4}$, Venkat Shivudu $\mathrm{K}^{2}$, Ram Reddy GP $^{3}$}

1. PG-Scholar, 2. Reader, 3. Professor and H.O.D, Dept. of Ayurveda Siddhanta, 4. PG Scholar, Dept of Rasa Shastra

Sri Venkateswara Ayurvedic College, Tirupati, Andhra Pradesh

\begin{abstract}
Kasa is one of the most common ailments afflicting the Pranavaha Srotas. Kaphaja Kasa has been considered to be the cutting edge of the Doshic type of Kasa, which if neglected or mismanaged, may serve as the substratum for the emergence of a good number of disorders such as Kshataja Kasa, Kshayaja Kasa and Tamaka Swasa etc., which are very difficult to manage.

This clinical study was carried out to evaluate the efficacy of Hareetakyadi Gutika in patients suffering from Kaphaja Kasa by selecting 30 patients in SV Ayurvedic Medical College Hospital, Tirupati during the period 2011-2012. Patients were given Hareetakyadi Gutika in a dose of $12 \mathrm{gm}$ per day in divided doses for 14 days and effect was evaluated on pre-test and post-test design. Statistically significant $(\mathrm{p}<0.01)$ results were seen in the subjective symptoms like Mandagni, Gourava, Nishteeva etc., and objective signs like ESR, Neutrophils and Eosinophils counts giving a conclusion that Hareetakyadi Gutika is an effective treatment for Kaphaja Kasa.
\end{abstract}

Key words: Pranavaha Srotas, Kaphaja Kasa, Hareetakyadi Gutika

\section{Introduction:}

In recent years, there has been an extraordinary increase of incidence related to Respiratory system. According to National center for health statistics, 62 million cases of common cold and cough occurs each year. Cough is the fifth most common symptom for which patients seeks medical care.

Kasa has been described under various categories in the classics of Ayurveda - as independent disease $(1,2)$, Symptom (3) Complication (4) and sequel.

\section{*Corresponding Author:}

\section{Deeja CR}

P G Scholar,

S V Ayurvedic College, Tirupathi.

Contact no: +91-8125700893

Email: drdeeja.009@gmail.com
Kaphaja Kasa is a common Upper Respiratory tract ailment prevalent now a days and it is increasingly annoying and irritating the individual in his routine activity.

Ayurveda has a lot to offer in this regard. Vata and Kapha are the two key pathological factors involved in the Samprapti of Kaphaja Kasa (5). Hareetakyadi Gutika is having Kapha Vatahara property. Hence, this effort was made to access the action of drug in Kaphaja Kasa.

\section{Disease review:}

Kaphaja Kasa consists of two words "Kapha" and "Kasa". The word Kapha is derived from the root $\mathrm{Ke}$, meaning "Shirasi Kena Jalena va palathi" 
(6), that which is produced in the Shiras and nourished by jala. Acharya Charaka has defined Kasa as "Shushko Va Sa Kapho Va api Kasanath Kasaha" means release of obstructed vayu resulting in the production of abnormal sound in the process, which may be productive or dry (7).

\section{Nidana:}

The Nidanas mentioned in the classics are Guru, Abhishyandi, Madura, Picchila, Snigdha Ahara sevana, Divaswapna, Vicheshtana,
Samprapti: (9)

Kapha prakopaka nidana i.e. Ahara and vihara will leads to Kapha vriddhi which results in Agnimandhya. Due to Agnimandhya - Amarasa will be formed which results in Rasadathu dusthi. Rasadathu dusthi may lead to malarupi Kaphavrudhi, which will cause srotosangha (Pranavaha), due to which Vatavarodha occurs; this leads to Vimarga gamana of vata resulting in occurrence of Kaphaja Kasa.

Dhoomopaghata (8).

\section{Flow chart no: 1}
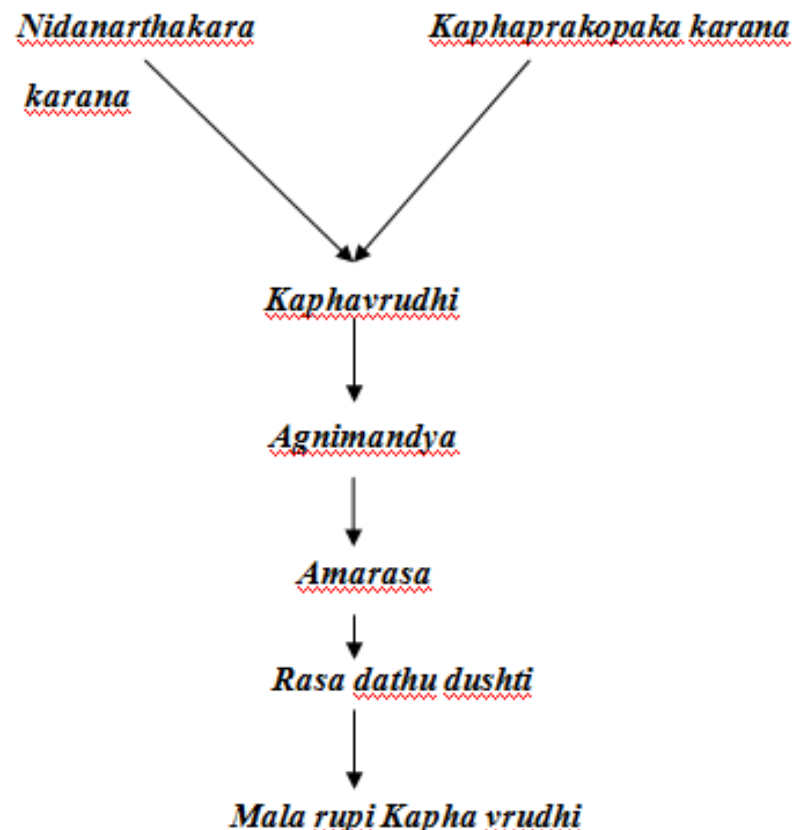

Mala rupi Kapha vrudhi

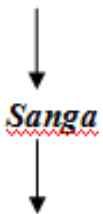

Vata avarodha

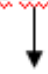

Vata prakopaka karana $\longrightarrow$ Vata Vimarga gamana

Kaphaja Kasa 
Table no: 1: Showing the Samprapti ghataka's of Kaphaja Kasa

\begin{tabular}{|l|l|}
\hline Dosha & Kapha, Vata \\
\hline Dushya & Rasa \\
\hline Agni & Jatharagni mandya \\
\hline Ama & Jatharagni mandya janya ama \\
\hline Srotas & Pranavaha \& Rasavaha \\
\hline Sroto dusthi & Sanga \\
\hline Udbhavasthana & Amashaya \\
\hline Sancharasthana & Rasayani (Srotas) \\
\hline Adhishtana & Urah pradesha \\
\hline Vyaktasthana & Kantha, Mukha \\
\hline Rogamarga & Abhyantara \\
\hline
\end{tabular}

\section{Rupa:}

Table no: 2 Showing Visishta lakshanas of Kaphaja Kasa (10)

\begin{tabular}{|l|l|}
\hline 1. & Kasa (Cough) \\
\hline 2. & Bahala, Snigda, Sweta Nishteevana (Expectoration) \\
\hline 3. & Aruchi (Tastelessness) \\
\hline 4. & Gourava (Heaviness) \\
\hline 5. & Sira soola (Headache) \\
\hline 6. & Mandagni (Loss of apetite) \\
\hline 7. & Peenasa (Running nose) \\
\hline 8. & Utklesa (Excitation) \\
\hline 9. & Kanthe kandu (Itching sensation in throat) \\
\hline 10. & Swarabhedha (Hoarseness of voice) \\
\hline
\end{tabular}

Note:

Acharya Charaka and Susruta have mentioned first eight symptoms in Kaphaja Kasa lakshanas and last the two are associated symptoms.

Table no: 3: Showing interrelation between Lakshana, Dosha, Vikalpa, Dushya, Srotas \& Sthana in Kaphaja Kasa

\begin{tabular}{|l|l|l|l|l|l|}
\hline Lakshanas & Dosha & Vikalpa & Dushya & Srotas & Sthana \\
\hline Kasa & $\mathrm{K}, \mathrm{V}$ & Karma & $\mathrm{R}$ & $\mathrm{P}, \mathrm{Ra}$ & Mukha \\
\hline $\begin{array}{l}\text { Bahala, Snigda, Sweta } \\
\text { shteevana }\end{array}$ & $\mathrm{K}$ & Drava & $\mathrm{R}$ & $\mathrm{P}$ & Uras \\
\hline Aruchi & $\mathrm{K}$ & Karma & $\mathrm{R}$ & $\mathrm{A}, \mathrm{Ra}$ & Mukha \\
\hline Gourava & $\mathrm{K}$ & Guru & $\mathrm{R}$ & $\mathrm{R}$ & Sarvataha \\
\hline Sira soola & $\mathrm{V}$ & Karma & $\mathrm{R}$ & $\mathrm{A}$ & Siras \\
\hline Swarabhedha & $\mathrm{V}$ & Ruksha & $\mathrm{R}$ & $\mathrm{Ra}, \mathrm{A}$ & Mukha \\
\hline Peenasa & $\mathrm{K}$ & Drava & $\mathrm{R}$ & $\mathrm{P}$ & Nasa \\
\hline Kanthe kandu & $\mathrm{K}$ & Karma & $\mathrm{R}$ & $\mathrm{P}$ & Kantha \\
\hline Utklesa & $\mathrm{K}$ & Karma & $\mathrm{R}$ & $\mathrm{A}$ & Amashaya \\
\hline
\end{tabular}




\begin{tabular}{|l|l|l|l|l|l|}
\hline Mandagni & K & Guru & R & Ra & Amashaya \\
\hline
\end{tabular}

Note: $\mathrm{V}=$ Vata $; \mathrm{K}=$ Kapha $; \mathrm{R}=$ Rasa $; \mathrm{P} \quad=$ Pranavaha $; \mathrm{A}=$ Annavaha $; \mathrm{Ra}=$ Rasavaha

Drug review:

Hareetakyadi Gutika - Chakradatta Kasarogadhikara (11)

Table No: 4: Showing the ingredients of Hareetakyadi Gutika:

\begin{tabular}{|l|l|l|l|c|}
\hline S.No & Ingredients & Botanical name & Part used & Quantity \\
\hline 1. & Hareetaki & $\begin{array}{l}\text { Terminalia chebula } \\
\text { retz }\end{array}$ & Phala majja & 1 part \\
\hline 2. & Nagara & Zingiber officinale & Kanda & 1 part \\
\hline 3. & Musta & Cyperus rotundus & Kanda & 1 part \\
\hline 4. & Guda & \multicolumn{2}{|c|}{ Double to above drugs } \\
\hline
\end{tabular}

Mode of preparation:

Hareetaki churna, Nagara churna and Musta churna were taken in equal quantity and to this double quantity of Guda was added and made into pills

Properties of ingredients of Hareetakyadi Gutika:

Table no: 5: Showing properties of ingredients

\begin{tabular}{|l|l|l|l|l|}
\hline Dravya & Rasa & Guna & Doshaghnata & Karma \\
\hline Hareetaki & $\begin{array}{l}\text { Kashaya }++ \\
\text { Pacharasa }\end{array}$ & $\begin{array}{l}\text { Ruksha, } \\
\text { Laghu }\end{array}$ & Tridoshahara & $\begin{array}{l}\text { Anulomana } \\
\text { Rasayana } \\
\text { Kasahara } \\
\text { Krimighna }\end{array}$ \\
\hline Nagara & Katu & $\begin{array}{l}\text { Laghu, } \\
\text { Tikshna }\end{array}$ & Vata Kaphahara & $\begin{array}{l}\text { Deepana } \\
\text { Bhedana } \\
\text { Kasahara }\end{array}$ \\
\hline Musta & Katu, Tikta & $\begin{array}{l}\text { Ruksha, } \\
\text { Laghu }\end{array}$ & $\begin{array}{l}\text { Kapha } \\
\text { Pitta hara }\end{array}$ & $\begin{array}{l}\text { Deepana } \\
\text { Pachana } \\
\text { Kapharogahara }\end{array}$ \\
\hline Guda-Purana & Madura & $\begin{array}{l}\text { Laghu, } \\
\text { Pathya }\end{array}$ & $\begin{array}{l}\text { Vata } \\
\text { Pitta hara }\end{array}$ & Anabhsyandi \\
\hline
\end{tabular}

Administration of the drug:

Mode of administration - orally

Dose - 1 Karsha i.e12 gm of gutika in divided doses i.e. on and off (Patient were advised to take the Gutika as per their convenience depending on the severity of the cough. Maximum dose - up to $12 \mathrm{gm}$, minimum dose- $6 \mathrm{gm}$ )

Anupana - Hot water (Ushna jala)

Duration of treatment- 14 days

Follow up-After 15 days of treatment

Type of statistical study:

Randomized open trial

\section{Aims and objectives}

To evaluate the clinical efficacy of Hareetakyadi Gutika in the selected cases of Kaphaja Kasa patients.

\section{Materials and methods}

Diagnostic criteria:

a. Diagnosis was made based on Symptomatology.

b. Kaphaja Kasa less than 10 days duration with Sputum of white in color and thick in consistency were taken for the study. 


\section{Statistical criteria:}

Patients were selected by random sampling technique i.e. irrespective of sex, caste, religion \& occupation; they were advised to visit the hospital every 2 weeks for regular check up \& to assess the effect of the therapy there by. In case any patient leaves the trial without completing 14 days treatment and 15 days follow up there after, he / she have declared as dropped out from the research work.

\section{Criteria for selection of cases:}

A. Inclusion Criteria:

a. Patients having classical signs and symptoms of Kaphaja Kasa.

b. Patients having age above 10 years \& below 60 years.

B. Exclusion Criteria:

a. Patients with complication of Kasa i.e., Chronic obstructive Bronchitis, Tuberculosis, Bronchiectasis, Lung abscess, Pulmonary edema resulting from Cardiac \& Renal disease, Pneumonia have been excluded.

b. Patients with severe form of other systemic disorders and metabolic diseases.

c. Pregnant women and lactating mothers.

\section{Criteria for Assessment}

Assessment was done under the two headings, subjective and objective assessment.

\section{Subjective Assessment}

Main signs and symptoms and associated complaints were given different scores according to their severity, they were recorded before and after treatment

Grading pattern for subjective
assessment:
Table no:6: Grading-Kasa
\begin{tabular}{|l|l|l|}
\hline None & No Complaints & 0 \\
\hline Mild & Intermittent cough & 1 \\
\hline
\end{tabular}

\begin{tabular}{|l|l|l|}
\hline Moderate & Constant cough & 2 \\
\hline Severe & Worsened cough & 3 \\
\hline
\end{tabular}

Table no:7: Grading-Quality of Sputum

\begin{tabular}{|l|l|c|}
\hline None & No Productive cough & 0 \\
\hline Mild & $\begin{array}{l}\text { Serous expectoration with } \\
\text { traces of thick Sputum }\end{array}$ & 1 \\
\hline Moderate & $\begin{array}{l}\text { Moderately thick white in } \\
\text { color }\end{array}$ & 2 \\
\hline Severe & $\begin{array}{l}\text { Thick large quantity of } \\
\text { solid white Sputum }\end{array}$ & 3 \\
\hline
\end{tabular}

Table no: 8: Grading- Aruchi

\begin{tabular}{|l|l|l|}
\hline None & $\begin{array}{l}\text { Equal willing to all kinds } \\
\text { of food }\end{array}$ & 0 \\
\hline Mild & $\begin{array}{l}\text { Willing to some specific } \\
\text { foods }\end{array}$ & 1 \\
\hline Moderate & Willing only one rasa & 2 \\
\hline Severe & $\begin{array}{l}\text { Willing to only most liking } \\
\text { foods, } \\
\text { (Ushna Ahara) }\end{array}$ & 3 \\
\hline
\end{tabular}

Table no: 9: Grading-Gourava

\begin{tabular}{|l|l|c|}
\hline None & Not present & 0 \\
\hline Mild & $\begin{array}{l}\text { Frequency of Gourava 1 to } \\
\text { 2 times per day }\end{array}$ & 1 \\
\hline Moderate & $\begin{array}{l}\text { Frequency of Gourava 3 to } \\
\text { 4 times per day }\end{array}$ & 2 \\
\hline Severe & Gourava present daily & 3 \\
\hline
\end{tabular}

Table no: 10: Grading-Shira soola

\begin{tabular}{|l|l|c|}
\hline None & Absent & 0 \\
\hline Mild & $\begin{array}{l}\text { Soola is present only at } \\
\text { morning and after intake of } \\
\text { food }\end{array}$ & 1 \\
\hline Moderate & $\begin{array}{l}\text { Soola is present only at } \\
\text { time of cough }\end{array}$ & 2 \\
\hline Severe & $\begin{array}{l}\text { Soola is disturbing daily } \\
\text { routine. }\end{array}$ & 3 \\
\hline
\end{tabular}

Table no: 11: Grading- Swarabeda

\begin{tabular}{|l|l|}
\hline None & 0 \\
\hline Mild & 1 \\
\hline Moderate & 2 \\
\hline Severe & 3 \\
\hline
\end{tabular}


Table no: 12: Grading-Peenasa

\begin{tabular}{|l|l|c|}
\hline None & No Nasal discharge & 0 \\
\hline Mild & $\begin{array}{l}\text { Nasal discharge in less } \\
\text { quantity }\end{array}$ & 1 \\
\hline Moderate & $\begin{array}{l}\text { Yellowish nasal discharge } \\
\text { with heaviness in head and } \\
\text { low grade fever }\end{array}$ & 2 \\
\hline Severe & $\begin{array}{l}\text { Yellowish discharge in } \\
\text { large quantity with } \\
\text { headache and fever }\end{array}$ & 3 \\
\hline
\end{tabular}

Table no: 13: Grading-Kanthe kandu

\begin{tabular}{|l|l|}
\hline None & 0 \\
\hline Mild & 1 \\
\hline Moderate & 2 \\
\hline Severe & 3 \\
\hline
\end{tabular}

Table no: 14: Grading-Utklesa

\begin{tabular}{|l|l|c|}
\hline None & No Utklesa & 0 \\
\hline Mild & Utklesa often & 1 \\
\hline Moderate & $\begin{array}{l}\text { Often, but relieved by } \\
\text { vomiting }\end{array}$ & 2 \\
\hline Severe & $\begin{array}{l}\text { No relief even after } \\
\text { vomiting }\end{array}$ & 3 \\
\hline
\end{tabular}

Table no: 15: Grading- Mandagni

\begin{tabular}{|l|l|l|}
\hline None & Digestion within 3 hours & 0 \\
\hline Mild & Digestion within 3-6 hours & 1 \\
\hline Moderate & Digestion wit in 6-9 hours & 2 \\
\hline Severe & $\begin{array}{l}\text { Digestion will take 9- 12 } \\
\text { hours }\end{array}$ & 3 \\
\hline
\end{tabular}

\section{Objective Assessment:}

Under the objective parameters, laboratory findings were assessed as follows: ESR, Neutrophil and Eosinophil counts were done before treatment, after treatment and for follow up. Data is statistically analyzed by using ' $t$ ' test.

\section{Assessment of total effect of therapy:}

Based on improvement in the subjective and objective parameters of Kaphaja Kasa, the following criteria was adopted to evaluate the total efficacy of the therapy.
Table no: 16: Showing criteria for accessing the total efficacy of therapy

\begin{tabular}{|l|l|}
\hline $\begin{array}{l}\text { Complete } \\
\text { remission }\end{array}$ & $\begin{array}{l}75-100 \% \text { relief in } \\
\text { signs and symptoms } \\
\text { of Kaphaja Kasa }\end{array}$ \\
\hline $\begin{array}{l}\text { Moderate } \\
\text { improvement }\end{array}$ & $\begin{array}{l}50-74 \% \text { relief in } \\
\text { signs and symptoms } \\
\text { of Kaphaja Kasa }\end{array}$ \\
\hline Mild improvement & $\begin{array}{l}25-49 \% \text { relief in } \\
\text { signs and symptoms } \\
\text { of Kaphaja Kasa }\end{array}$ \\
\hline No improvement & $\begin{array}{l}\text { Less than 25\% relief } \\
\text { in signs and } \\
\text { symptoms } \\
\text { Kaphaja Kasa }\end{array}$ \\
\hline
\end{tabular}

\section{Statistical evaluation:}

The obtained information was analyzed statistically in terms of Mean score (x), Standard Deviation (S.D.) and Standard Error (S.E.). Paired t-Test was carried out at the level of $0.05,0.01$ and 0.001 of $\mathrm{P}$ levels. The results were interpreted as

$\mathrm{P}>0.05$ - Insignificant

$\mathrm{P}<0.05-$ Significant

$\mathrm{P}<0.01$ and $\mathrm{P}<0.001$ - Highly significant

\section{Observations:}

General discussion:

The general observations found in 30 patients of Kaphaja Kasa registered in this study are as follows:

\section{Age wise:}

Majority of the patients i.e. $43.33 \%$ belong to the age group of $20-30 \mathrm{yrs}$, followed by $23.33 \%$ in $30-40$ yrs age group. There is no age specification mentioned in the disease Kaphajakasa. In this study, the probable cause for increasing incidence in 20-40 age groups may be because Persons of this group i.e. 20 to 40 years are more exposed towards the changing external environment owing to their Vihara \& irregularities in diet like nidana for several years, which leads to occurrence of this disease. 
Sex wise:

The majority of patients i.e. $66.66 \%$ were male and remaining $33.33 \%$ were female. This may be due to cumulative effect of following factors especially in male; these are smoking, unavoidable exposure to external pattern, responsibilities to earn for family member to comparison to females.

\section{Occupation wise:}

It was observed that more number of patients belongs to labor group (50\%) followed by, housewives $(26.66 \%)$, and students $(16.66 \%)$. This is because more chance of exposure to allergens like dust, smoke, house dust mite, pollens etc. Many patients admitted that symptoms are going to disappear by change of place. It clearly shows their exposure to allergens in their occupation.

\section{Socio Economic wise:}

Maximum numbers of patients observed were from poor class family i.e. $50 \%$ followed by $30 \%$ of middle class people and remaining $20 \%$ of them belonging to well to do family. This might be due to improper hygiene and decreased health awareness in those classes.

\section{Agni wise:}

Mandagni was observed in 56.66. Because as excessive Kapha leads to Mandagni. In Kaphaja Kasa, Kapha is the main dosha and here Agni remains in vikruta state. This creates an imbalance of dosha state and hence cause of the disease.

\section{Predominant Rasa wise:}

Maximum percentage of patients $43.33 \%$ were taking predominantly Madhura rasa .Excessive intake of sweets leads to Kapha Prakopa that in turn leads to Kaphaja Kasa.
Addiction wise:

According to Text Book of Harsh Mohan pathology, the pathology of smoking creates Respiratory problems and ultimately disease COPD (Nidannaarthakara Roga). It is single most factor for causing malignancy of lungs.

According to Ayurveda, it is Dhuma (fumes) factor, which continuously irritate the inner wall of alveoli and cause Pranavaha Sroto dusthi. Tobacco is also one factor along with smoking causing cancer of larynx or Oropharynx, parts of upper respiratory tract. Here in the current study $50 \%$ patients were smokers and $40 \%$ were addicted to tobacco chewing.

$30 \%$ of patients are tea addicts as it is one of the most popular refreshing drink of India in routine .The modern research shows that it causes bad effect on gastric secretion i.e., Mandagni, which ultimately affects dushya Rasa dhatu and vitiation of Vata and Kapha dosha.

\section{History of Recurrent URTI:}

The frequency of Kaphaja Kasa is much higher in a person who is recurrently suffering from cold. Acharya Susruta explained that if Pratisyaya is untreated it leads to Kasa. In this study, $56.66 \%$ of cases had history of recurrent URTI.

\section{Bowel habit:}

In current study $56.66 \%$ of patients having irregular bowel habits, which indicate dominancy of Vata. These persons were having habitual Constipation leading to vitiation of Vayu. This is one of the major causes of the disease, which leads to Pratilomagati of Vayu \& thus plays an important role in the pathology of Kasa.

\section{Periodicity of cough:}

Maximum numbers of 23 (76.66\%) cases were having seasonal periodicity. This shows dependency of disease over season. 
Table No: 17 showing evaluation of the effect of Hareetakyadi gutika on Subjective parameters

\begin{tabular}{|l|l|l|l|l|l|l|l|l|l|l|}
\hline S.No & Symptoms & N & B.T & A.T & Mean & $\begin{array}{l}\text { Relief } \\
\mathbf{\%}\end{array}$ & S.D & S.E & t & p \\
\hline 1. & Kasa & 30 & 2.3 & 0.4 & 1.9 & $82 \%$ & 0.76 & 0.14 & 13.7 & $<0.01$ \\
\hline 2. & Nishteevana & 30 & 2.17 & 0.33 & 1.83 & $84 \%$ & 0.69 & 0.13 & 14.4 & $<0.01$ \\
\hline 3. & Aruchi & 30 & 1.67 & 0.27 & 1.4 & $84 \%$ & 1.16 & 0.21 & 6.6 & $<0.01$ \\
\hline 4. & Gourava & 30 & 1.63 & 0.2 & 1.43 & $88 \%$ & 1.25 & 0.23 & 6.3 & $<0.01$ \\
\hline 5. & Sira soola & 30 & 0.67 & 0.2 & 0.47 & $70 \%$ & 0.86 & 0.16 & 3.0 & $<0.01$ \\
\hline 6. & Swarabeda & 30 & 0.4 & 0.1 & 0.3 & $75 \%$ & 0.79 & 0.15 & 2.1 & $<0.05$ \\
\hline 7. & Peenasa & 30 & 1.2 & 0.23 & 0.97 & $81 \%$ & 0.99 & 0.18 & 5.3 & $<0.01$ \\
\hline 8. & Kanthe kandu & 30 & 1.63 & 0.37 & 1.27 & $78 \%$ & 1.11 & 0.21 & 6.2 & $<0.01$ \\
\hline 9. & Utklesa & 30 & 1.4 & 0.33 & 1.07 & $76 \%$ & 1.14 & 0.21 & 5.1 & $<0.01$ \\
\hline 10. & Mandagni & 30 & 1.6 & 0.17 & 1.43 & $90 \%$ & 1.19 & 0.22 & 6.6 & $<0.01$ \\
\hline
\end{tabular}

Table no: 18 Showing effect of therapy on subjective parameters of Kaphaja Kasa

\begin{tabular}{|l|l|}
\hline Effect on Kasa & $\begin{array}{l}\text { Statistically highly significant relief }(\mathrm{p}<.01) \\
\text { Percentage wise relief is } 82 \%\end{array}$ \\
\hline Effect on Nishteevana & $\begin{array}{l}\text { Statistically highly significant relief }(\mathrm{p}<.01) \\
\text { Percentage wise relief is } 84 \%\end{array}$ \\
\hline Effect on Aruchi & $\begin{array}{l}\text { Statistically highly significant relief }(\mathrm{p}<.01) \\
\text { Percentage wise relief is } 84 \%\end{array}$ \\
\hline Effect on Gourava & $\begin{array}{l}\text { Statistically highly significant relief }(\mathrm{p}<.01) \\
\text { Percentage wise relief is } 88 \%\end{array}$ \\
\hline Effect on Sira soola & $\begin{array}{l}\text { Statistically highly significant relief }(\mathrm{p}<.01) \\
\text { Percentage wise relief is } 70 \%\end{array}$ \\
\hline Effect on Swarabeda & $\begin{array}{l}\text { Statistically significant relief }(\mathrm{p}<.05) \\
\text { Percentage wise relief is } 75 \%\end{array}$ \\
\hline Effect on Peenasa & $\begin{array}{l}\text { Statistically highly significant relief }(\mathrm{p}<.01) \\
\text { Percentage wise relief is } 81 \%\end{array}$ \\
\hline Effect on Kanthe kandu & $\begin{array}{l}\text { Statistically highly significant relief }(\mathrm{p}<.01) \\
\text { Percentage wise relief is } 78 \%\end{array}$ \\
\hline Effect on on Utklesa & $\begin{array}{l}\text { Statistically highly significant relief }(\mathrm{p}<.01) \\
\text { Percentage wise relief is } 76 \%\end{array}$ \\
\hline Effect on Mandagni & $\begin{array}{l}\text { Statistically highly significant relief }(\mathrm{p}<.01) \\
\text { Percentage wise relief is } 90 \%\end{array}$ \\
\hline
\end{tabular}




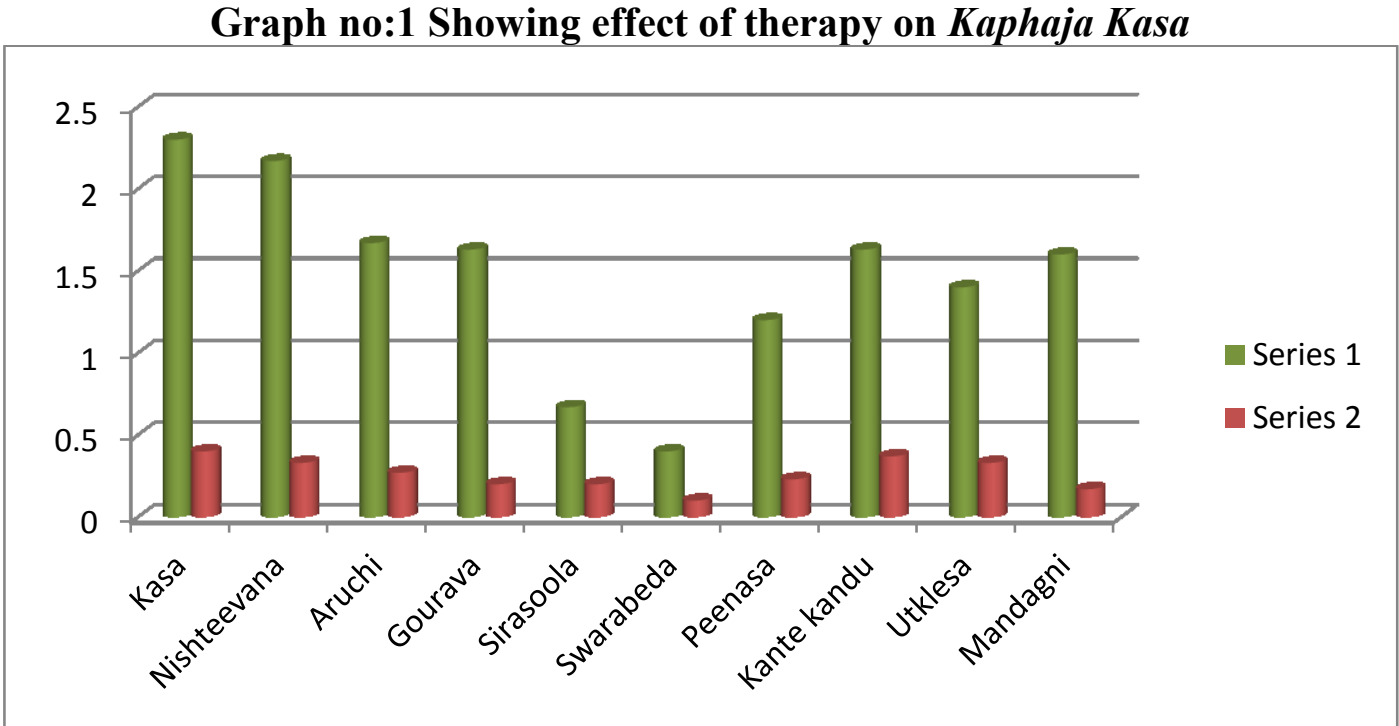

Note: Series 1 - Before treatment mean; Series 2 - After treatment mean

Table No: 19: Showing evaluation of the effect of Hareetakyadi gutika on objective parameters

\begin{tabular}{|l|l|l|l|l|l|l|l|l|l|}
\hline $\begin{array}{l}\text { Objective } \\
\text { parameter }\end{array}$ & $\mathbf{N}$ & BT & AT & Mean & Relief & S.D & S.E & t & P \\
\hline ESR & 30 & 29.6 & 25.4 & 13.4 & $45 \%$ & 8.28 & 1.51 & 8.9 & $<.01$ \\
\hline $\mathrm{N}$ & 30 & 66 & 59.7 & 6.33 & $9.6 \%$ & 4.77 & .87 & 7.3 & $<.01$ \\
\hline $\mathrm{E}$ & 30 & 6.03 & 4.0 & 2 & $33 \%$ & 1.17 & .37 & 5.4 & $<.01$ \\
\hline
\end{tabular}

- The effects of therapy on ESR is highly significant results at $\mathrm{p}<0.01$ obtained, i.e. the improvement in the ESR level is $45 \%$

- The effects of therapy on Neutrophil is highly significant results at $\mathrm{p}<0.01$, obtained, 9.6\% improvement in Neutrophil level.

- The effect of therapy on Eosinophils is highly significant results at $p<0.01$, obtained 33 $\%$ improvement in Eosinophils levels.

Table no: 20 Showing overall assessment of the clinical trial

\begin{tabular}{|l|l|l|}
\hline Result & No. of patients & \% \\
\hline Complete cure & 25 & $83 \%$ \\
\hline Moderate relief & 4 & $13 \%$ \\
\hline Mild relief & 1 & $3 \%$ \\
\hline Not cured & 0 & $0 \%$ \\
\hline
\end{tabular}

\section{Discussion:}

Cough is the commonest Respiratory symptom that has been experienced by every human being. It is having greater influence of environmental factors such as pollutants, allergens, smoke, dust, etc (12), and this is unavoidable circumstance in the life. The primary action of currently available cough suppressants have significant side effects such as constipation, respiratory depression, dependence, drowsiness etc, 
hence there is a current huge unmet need for the development of safe, effective therapeutic options in the treatment of persistent cough as alternative to existing medications.

In Kaphaja Kasa, Kapha dosha obstructs the Vata gati and there by Vata takes abnormal path, so while treating one should focus on Kapha nirharana as well as normalizing the Vata gati.

Hareetakyadi Gutika is having Ushna veerya which mitigates the Vata and Kapha, which directly antagonizing the Sheeta guna of the Vata and Kapha. Deepana and Pachana property of the Nagara, Musta and Guda makes Agnivardhana and Ama pachana at the Amashaya, therefore, the ultimate goal is achieved i.e. Kapha gets mitigate at its own seat. Hence, the vitiation of the kapha is under control.

In addition, the above said properties, also enhance the Dhatwagni of the rasa dhatu which also helps in the controlling the vitiated Kapha, as the Kapha is mala of the rasadhatu. Hareetaki having gunas like Vaataanulomaka, Tridoshhara, which helps in mitigating Kapha and giving anulomana gati to Vata, which also helps in Vaatashamana. Most of the drugs, have Kashaya, Tikta, Katu rasa that helps to alleviate Kapha dosha. Hareetaki and Nagara both of them works in Kasa. So with this yoga can achieve better result in this disease.

The aim of the present study was to evaluate effect of an Ayurvedic formulation Hareetakyadi Gutika in patients of Kaphaja Kasa. Symptomatic relief was observed in

$82 \%, 84 \%, 84 \%, 88 \%$ and $81 \% \quad$ c regarding Kasa, Nishteeva, Aruchi, Gourava and in Peenasa. Mean ESR level drooped from 29.6 to 25.4, mean Neutrophils count dropped from66 to 60.7 similarly mean Eosinophil count drooped from 6.03 to 4.1 in the 14 days of study.

\section{Conclusion:}

Kaphaja Kasa is a simple Productive Cough associated with cold and throat infection with recent origin and without much infection.

Hareetakyadi Gutika was highly significant in relieving Mandagni, Gourava and Nishteeva and other symptoms with $p$ value $<0.01$. It reduced E.S.R. to certain extent and normalized Eosinophil and Neutrophil count.

\section{Recommendation for future study:}

Hareetakyadi Gutika and other Yogas mentioned for Kaphaja Kasa can be studied Comparatively.

Present study pattern can be continued in the form of prospective clinical Study with increased sample size.

As the present study was limited to 14 days, it was not possible to observe the Optimum efficacy of the Trial drug in chronic cases. Further drug may give for more number of days to observe in chronic cases as treatment for best result.

\section{References:}

1. Jadhavji Trikamji Acharya, Charaka samhita, Varanasi, Chaukhambha Sanskrit Sansthan ; 2011, 433p

2. Jadhavji Trikamji Acharya, Susruta Samhita, Varanasi, Chaukhambha Sanskrit Sansthan, 2012, 766p

3. Ramavalamba Sastri, Harita Samhita Varanasi, Prachya Prakasan; 1985, $232 p$

4. Ramavalamba Sastri, Harita Samhita Varanasi, Prachya Prakasan; 1985, $230 \mathrm{p}$

5. Jadhavji Trikamji Acharya, Charaka samhita, Varanasi, Chaukhambha Sanskrit Sansthan ; 2011, 433p .

6. Deva R.K, Shabda kalpa druma, part 2, $2516 \mathrm{p}$

7. Jadhavji Trikamji Acharya, Charaka samhita, Varanasi, Chaukhambha Sanskrit Sansthan ; 2011, 433p 
8. Jadhavji Trikamji Acharya, Charaka samhita, Varanasi, Chaukhambha Sanskrit Sansthan ; 2011, 433p

9. Charaka Samhita, Ayurveda deepika commentary, Jadhavji Trikamji Acharya, editor: Varanasi, Chokhambha Sanscrit Sansthan ; 2011, $433 p$

10. Susruta Sanhita, Nibhandha Sangraha commentary, Jadhavji Trikamji
Acharya, editor: Varanasi, Chokhambha Sanscrit Sansthan ; 2012, $766 \mathrm{p}$

11. Cheppat Achyuta Varrier, Chakradattam, 2007, 124p

12. Harrison's Principle's of Internal Medicine-vol.I 16th, McGraw Hill Publication USA2005, 242th chap., $1547 \mathrm{pp}$. 